\title{
Arguments against long-term conservative treatment of oesophageal strictures due to corrosive burns
}

\author{
JÓZSEF IMRE and MIKLÓS KOPP
}

The 1st Department of Surgery and Department of Radiology, Medical University, Szeged, Hungary

Thirty-two patients are presented with late complications after a corrosive burn of the oesophagus. From this group of 32 cases 11 had fistulae and mediastinal abscesses after perforation of the gullet; 11 patients developed a tight peptic stricture in the narrowed oesophagus due to traction-type hiatal hernia as a result of the longitudinal contraction of the fibrotic oesophagus ; cancer developed in the corrosive stricture in 10 patients, inoperable in five.

Arguments against long-term conservative treatment of narrowed and fibrotic oesophageal strictures are presented. Early operation gives final relief from dysphagia and prevents late complications. The risk of intrathoracic oesophageal replacement with a segment of bowel/colon or jejunum in uncomplicated cases is $2.4 \%$ in our series of 42 cases.

Patients with so-called benign strictures of the oesophagus due to a corrosive burn have beez subject to conservative treatment since Salzer (1920) advised early dilatation of such strictures. Dilatation certainly gives relief from the intense dysphagia and these patients learn what they can swallow without difficulty and many of them can live for years without untoward complaints (Gellis and Holt, 1942; Marchand, 1965; Moody and Garrett, 1969). However, life is usually not trouble-free. Many of these patients periodically need oesophagoscopy and dilatation when food blocks the narrowed segment of the oesophagus.

The usual causative corrosive chemical before the end of the thirties was lye $(\mathrm{KOH})$ at that time widely used as a cleaning agent in this country. Children drank it by accident, adults if they wanted to commit suicide. From 1920 to 1940 lye swallowing was common. Because of the great number of accidents lye has not been available without licence during the last 30 years, so that the frequency of corrosive burns has decreased.

In our country, as in many others, these patients are under the care of otolaryngologists. Acute cases with corrosive burns of the oesophagus are admitted to otolaryngological departments and are treated there as long as their problems can be handled. Patients who cannot be treated by conservative methods or who develop complications such as instrumental perforation are transferred to surgical units.
In the last eight years, since we started to dea? with oesophageal surgery in the 1 st Surgical De partment of our University, 61 patients have beek admitted with chronic corrosive strictures of the oesophagus, mainly from other otolaryngologicat departments. Of the 61 cases, 32 had severe late complications. The consequences of old corrosive oesophageal lesions in our series were as follows

(1) chronic mediastinal abscess or broncho oesophageal fistula due to perforation of the oesophagus in 11 patients;

(2) traction-type hiatal hernia due to contractioes of the fibrotic oesophageal wall in 11 patients;

(3) development of cancer in the corrosive stric ture of the eosophagus in 10 patients.

The dangers of repeated oesophagoscopy and dilatation in patients with corrosive strictures are well known. Perforation and fistulae are not infrequent results of this treatment. If the perfora tion is proximal to the narrow segment of the gullet, there is little chance of spontaneous healo ing, and radical treatment is necessary, consisting of oesophagectomy and oesophageal replacement or, in the worst septic cases, oesophageal bypass by a segment of bowel (Dor et al., 1960b; ImreHorváth, and Altorjay, 1968) (Fig. 1; Table N).

The existence of traction-type hiatal hernia is not widely known. The mechanism which we believe produces this type of hiatal hernia occure only in patients who have had a corrosive burrot The fibrotic oesophagus contracts and pulls up 8 pouch of stomach into the chest. These patients 

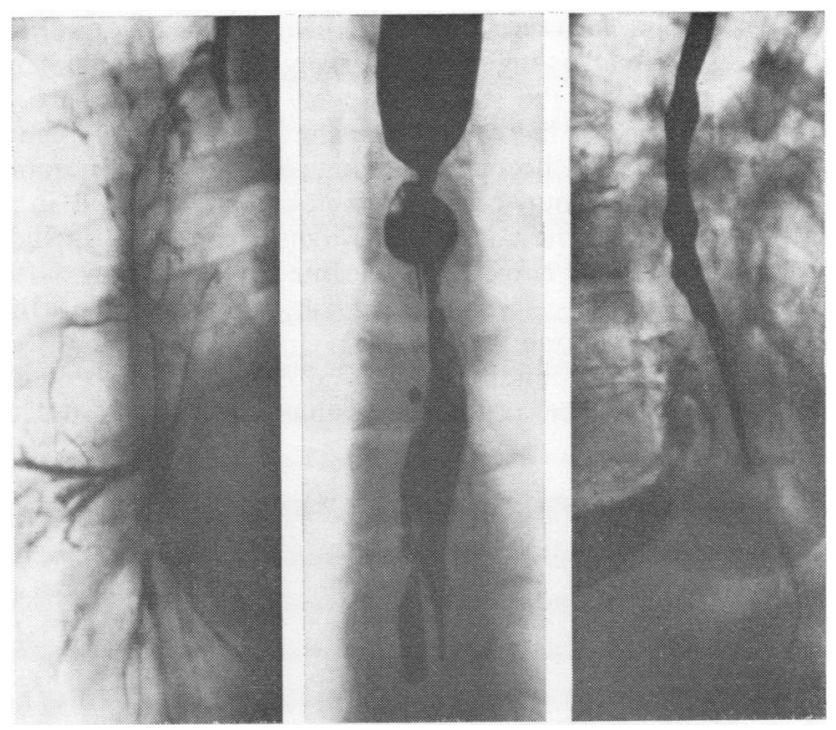

FIG. 1. Late consequences of dilatation of corrosive oesophageal strictures (see Table I). Left: Chronic oesophagobronchial fistula; the swallowed radio-opaque dye fills the bronchial tree on the left side. M.F., female aged 33. Middle: Chronic mediastinitis with multiple perforations of the oesophagus. B.I., female aged 43. Right: Oesophageal perforation and lung abscess. B.M., female aged 58.

T A B LE I DETAILS OF 11 PATIENTS WITH OESOPHAGEAL PERFORATION FOLLOWING CORROSIVE BURNS

\begin{tabular}{|c|c|c|c|c|c|c|c|}
\hline Patient & \multicolumn{2}{|c|}{ Sex/Age } & Complication & $\begin{array}{l}\text { No. of Years } \\
\text { Since Corrosive } \\
\text { Burn }\end{array}$ & $\begin{array}{c}\text { Year } \\
\text { of } \\
\text { Surgery }\end{array}$ & Treatment & Result \\
\hline K.I. & $\mathbf{F}$ & 25 & Chronic mediastinal abscess & 23 & 1965 & $\begin{array}{l}\text { Substernal oesophageal bypass } \\
\text { with left colon }\end{array}$ & Recovered \\
\hline M.F. & $\mathbf{F}$ & 33 & Oesophagobronchial fistula & 3 & 1965 & Substernal oesophageal bypass & Died after \\
\hline & $\mathbf{F}$ & 20 & $\begin{array}{c}\text { Oesophageal fistula and abscess of } \\
\text { upper lobe of left lung }\end{array}$ & 2 & 1965 & $\begin{array}{l}\text { Substernal oesophageal bypass } \\
\text { with ileocolic segment }\end{array}$ & $\begin{array}{l}\text { surgery } \\
\text { Complete }\end{array}$ \\
\hline B.I. & $\mathbf{F}$ & 43 & Chronic mediastinal abscess & 23 & 1965 & $\begin{array}{l}\text { Resection of scarred oesophagus, } \\
\text { replacement with ileocolic } \\
\text { segment }\end{array}$ & $\begin{array}{l}\text { Complete } \\
\text { recovery }\end{array}$ \\
\hline M.J. & $\mathbf{F}$ & 36 & Oesophagotracheal fistula & 3 & 1966 & Substernal oesophageal bypass & Complete \\
\hline Zs.I. & $\mathbf{F}$ & 61 & Chronic mediastinal abscess & 34 & 1967 & Resection of fibrotic oesophagus, & Complete \\
\hline B.M. & $\mathbf{F}$ & 58 & $\begin{array}{l}\text { Abscess in lower lobe of right } \\
\text { lung }\end{array}$ & 41 & 1968 & $\begin{array}{l}\text { Antethoracic oesophageal bypass } \\
\text { with jejunum }\end{array}$ & $\begin{array}{l}\text { recovery } \\
\text { Recovered }\end{array}$ \\
\hline K.J. & $\mathbf{F}$ & 46 & Chronic mediastinal abscess & 44 & 1969 & Resection of fibrotic oesophagus, & Complete \\
\hline N.M. & $\mathbf{F}$ & 56 & Oesophagotracheal fistula & 23 & 1971 & Gastiostomy feeding & Waiting for \\
\hline B.M. & $\mathbf{M}$ & 40 & $\begin{array}{l}\text { Abscess in lower lobe of right } \\
\text { lung }\end{array}$ & $?^{1}$ & 1971 & $\begin{array}{l}\text { Plastic tube endoprosthesis } \\
\text { inserted for } 14 \text { days into }\end{array}$ & $\begin{array}{c}\text { surgery } \\
\text { Recovered }^{2}\end{array}$ \\
\hline R.M. & $\mathbf{F}$ & 48 & $\begin{array}{l}\text { Perforation of cervical oesophagus; } \\
\text { mediastinal abscess }\end{array}$ & 46 & 1971 & $\begin{array}{l}\text { oesophagus } \\
\text { Gastrostomy }\end{array}$ & Recovered $^{2}$ \\
\hline
\end{tabular}


develop oesophagitis and a peptic stricture (in an already narrowed oesophagus) owing to gastro-oesophageal reflux. Dilatation of the stricture in these cases is pointless because it increases the reflux, and the fibrotic stricture becomes tighter. This type of hiatal hernia in our cases occurred between 25 and 69 years after the corrosive burn (Imre and Wooler, 1969) (Fig. 2; Table II).

There is little to add in the third group. Scar tissue is probably a premalignant condition (Alvarez and Colbert, 1963; Benedict, 1941;
Bigelow, 1953; Dor et al., 1960a; Imre anfํ Gergely, 1971; Sytnik and Petrov, 1968). Thē danger increases if there is chronic irritation a the site of the scar. Of the 10 patients with malig nancy in a fibrotic oesophagus, only five had $\alpha^{\infty}$ resectable growth, and in two cases the fact that the dense scar tissue included a malignant growth became evident only after surgery and histo $\omega$ logical examination of the resected oesophagust (Fig. 3; Table III).

The 32 cases presented here demonstrate the possible hazards of long-term conservative्ध

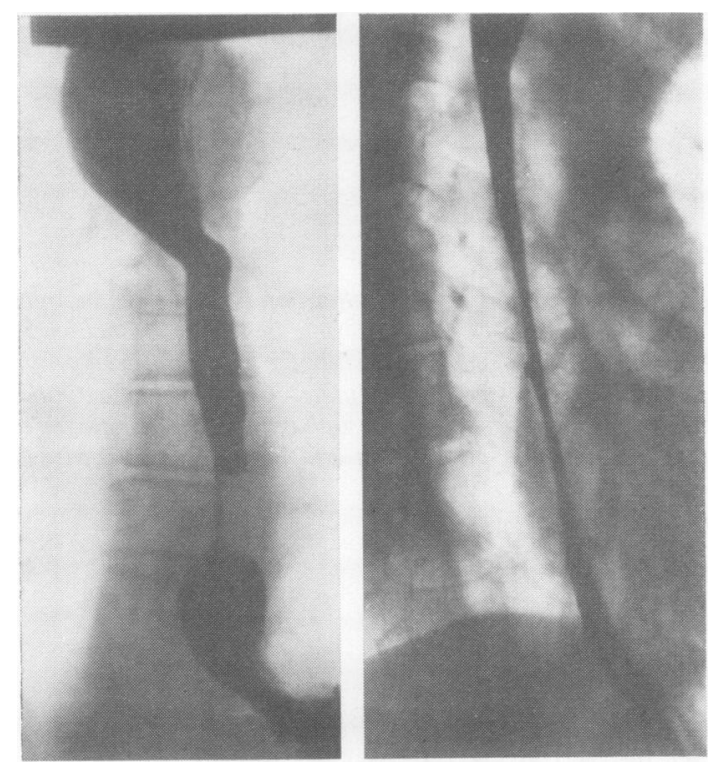

FIG. 2. Traction-type hiatal hernia and peptic stricture of oesophagus after corrosive burn (see Table II). Left: Tight peptic stricture 30 years after corrosive burn. Gy.L., male aged 67. Right: Peptic ulcer in scarred oesophagus 26 years after lye ingestion. J.J., male aged 33.

T A B LE II

DETAILS OF 11 PATIENTS WITH PEPTIC ULCERATION AFTER CORROSIVE BURNS OF THE OESOPHAGUS

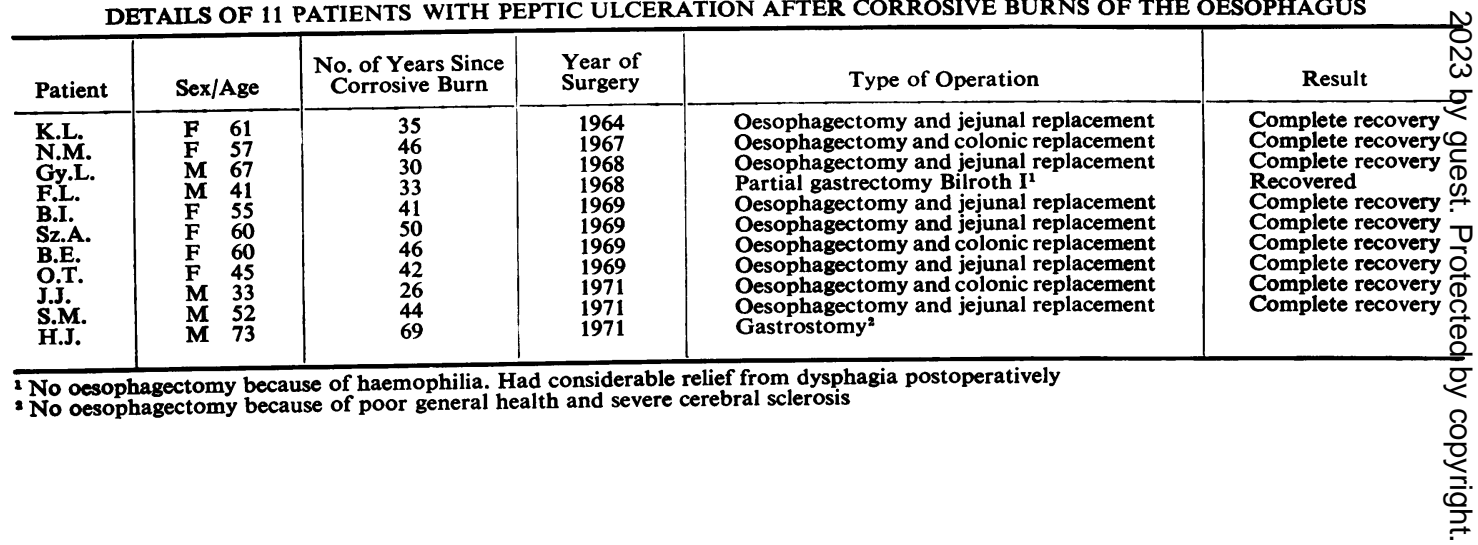


treatment of this so-called benign condition of the oesophagus. The treatment of patients with these complications is not easy because in the first group with perforation the mediastinum is infected; and in the second group with peptic oesophagitis due to hiatal hernia they are undernourished and sometimes elderly. We have a series of patients on whom oesophagectomy and intrathoracic oesophageal replacement have been performed for benign strictures of the gullet, 26
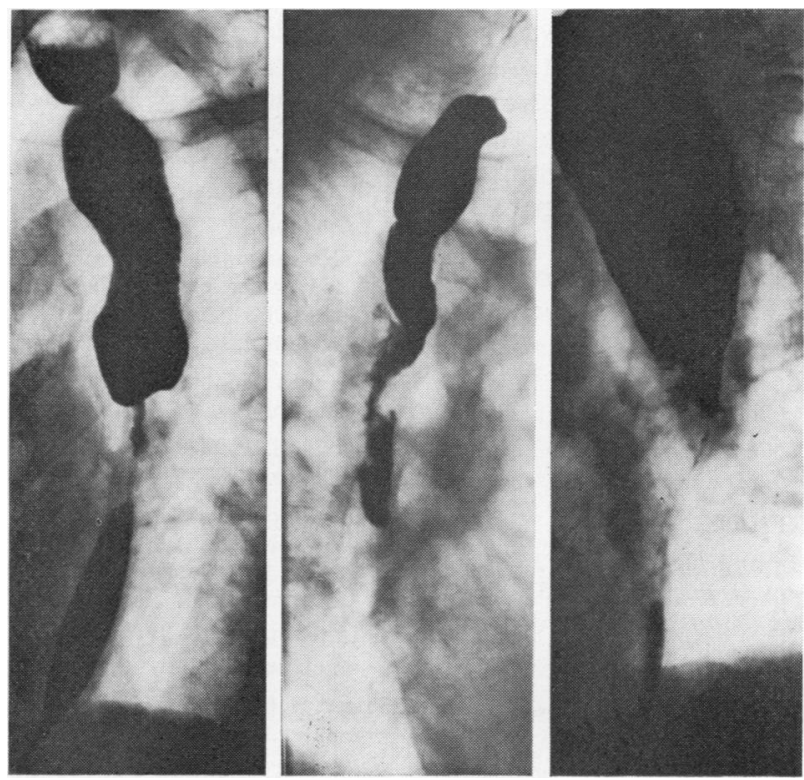

FIG. 3. Carcinoma at site of lye stricture (see Table III). Left: 54 years after corrosive burn, obstructive form. K.F., female aged 62. Middle: 49 years after corrosive burn, infiltrating form. B.L., male aged 53. Right: 45 years after corrosive burn, polypoid form. B.F., male aged 50.

\section{T A B L E I I I}

DETAILS OF 10 PATIENTS WHO DEVELOPED CANCER IN A FIBROTIC OESOPHAGUS

\begin{tabular}{|c|c|c|c|c|c|c|c|c|}
\hline Patient & \multicolumn{2}{|c|}{ Sex/Age } & $\begin{array}{c}\text { No. of } \\
\text { Years } \\
\text { Since } \\
\text { Corrosive } \\
\text { Burn }\end{array}$ & $\begin{array}{c}\text { Year } \\
\text { of } \\
\text { Surgery }\end{array}$ & Type of Operation & $\begin{array}{c}\text { Site } \\
\text { of } \\
\text { Carcinoma }\end{array}$ & Histology & Result \\
\hline V.S. & & 53 & 46 & 1965 & Oesophagectomy and & Lower third of & Squamous-cell carcinoma, & Died 2 yr \\
\hline K.F. & $\mathbf{F}$ & 62 & 54 & 1965 & $\begin{array}{l}\text { Jejunal replacement } \\
\text { Oesophagectomy and } \\
\text { jejunal replacement }\end{array}$ & $\begin{array}{l}\text { oesophagus } \\
\text { Middle third of } \\
\text { oesophagus }\end{array}$ & $\begin{array}{l}\text { non-differentiated } \\
\text { Squamous-cell carcinoma, }\end{array}$ & $\begin{array}{l}\text { atter surgery } \\
\text { Died } 1.5 \text { yr }\end{array}$ \\
\hline J.M. & $\mathbf{F}$ & 51 & 49 & 1965 & $\begin{array}{l}\text { Inoperable. Oesophagobron- } \\
\text { chial fistula; gastrostomy }\end{array}$ & & & \\
\hline K.I. & $\mathbf{F}$ & 27 & 24 & 1967 & Palliative bypass & $\begin{array}{l}\text { Upper third of } \\
\text { oesophagus }\end{array}$ & $\begin{array}{l}\text { Squamous-cell carcinoma, } \\
\text { well differentiated }\end{array}$ & $\begin{array}{l}\text { Died } 5 \text { mth } \\
\text { after } \\
\text { surgery }\end{array}$ \\
\hline & $\mathbf{F}$ & 52 & 46 & 1967 & $\begin{array}{l}\text { Inoperable. Palliative plastic } \\
\text { tube prosthesis }\end{array}$ & $\begin{array}{l}\text { Middle third of } \\
\text { oesophagus }\end{array}$ & $\begin{array}{l}\text { Squamous-cell carcinoma, } \\
\text { well differentiated }\end{array}$ & $\begin{array}{l}\text { Died } 7 \text { mth } \\
\text { after surgery }\end{array}$ \\
\hline B.L. & $\mathbf{M}$ & 53 & 49 & 1968 & $\begin{array}{l}\text { Oesophagectomy and } \\
\text { oesophagogastrostomy }\end{array}$ & $\begin{array}{l}\text { Middle third of } \\
\text { oesophagus }\end{array}$ & $\begin{array}{l}\text { Squamous-cell carcinoma, } \\
\text { well differentiated }\end{array}$ & Alive \\
\hline K.J. & $\mathbf{F}$ & 57 & 23 & 1968 & $\begin{array}{l}\text { Inoperable. Palliative plastic } \\
\text { tube prosthesis }\end{array}$ & $\begin{array}{l}\text { Middle third of } \\
\text { oesophagus }\end{array}$ & No biopsy & $\begin{array}{l}\text { Died } 4 \text { mth } \\
\text { after surgery }\end{array}$ \\
\hline B.J. & $\mathbf{F}$ & 47 & 19 & 1970 & $\begin{array}{l}\text { Inoperable. Palliative plastic } \\
\text { tube prosthesis }\end{array}$ & $\begin{array}{l}\text { Middle third of } \\
\text { oesophagus }\end{array}$ & $\begin{array}{c}\text { Squamous-cell carcinoma, } \\
\text { well differentiated }\end{array}$ & Died $5 \mathrm{mth}$ \\
\hline B.F. & $\mathbf{M}$ & 50 & 45 & 1971 & $\begin{array}{l}\text { Oesophagectomy and } \\
\text { oesophagogastrostomy }\end{array}$ & Middle third of & Squamous-cell carcinoma, & Alive and \\
\hline F.D. & $\mathbf{F}$ & 67 & 50 & 1971 & $\begin{array}{l}\text { Oesophagectomy and } \\
\text { oesophagogastrostomy }\end{array}$ & $\begin{array}{c}\text { Lower third of } \\
\text { oesophagus }\end{array}$ & $\begin{array}{l}\text { Squamous-cell carcinoma, } \\
\text { well differentiated }\end{array}$ & Alive \\
\hline
\end{tabular}


patients with a loop of jejunum (Allison, Wooler, and Gunning, 1957; Merendino and Dillard, 1955) and 16 with a segment of colon (Belsey, 1965). Of these 42 patients only one died, a mortality rate of $2.4 \%$. On the other hand, we have another series of patients in whom an intrathoracic operation was not possible and an antethoracic or substernal bypass operation was performed. This group includes the worst septic cases after perforation of the oesophagus. From these nine patients we have lost two, a mortality rate of $22 \%$. A comparison of the two groups of patients suggests the necessity for early operation before the development of complications.

Patients with a tight stricture of the oesophagus are good subjects for oesophageal replacement; the operation gives relief from dysphagia and prevents the complications described.

\section{REFERENCES}

Allison, P. R., Wooler, G. H., and Gunning, A. J. (1957). Esophagojejunogastrostomy. J. thorac. Surg., 33, 738.

Alvarez, A. F., and Colbert, J. G. (1963). Lye stricture of the oesophagus complicated by carcinoma. Canad. J. Surg., $6,470$.

Belsey, R. (1965). Reconstruction of the oesophagus with left colon. J. thorac. cardiovasc. Surg., 49, 33.

Benedict, E. B. (1941). Carcinoma of the oesophagus developing in benign stricture. New Engl. J. Med., 224, 408.
Bigelow, N. H. (1953). Carcinoma of the esophagus developing at the site of lye stricture. Cancer (Philad.), 6, 1159.

Dor, J., Depieds, R., Humbert, P., Bouyala, J. M., and $\frac{D}{7}$ Guérinel, J. (1960a). La cancerisation des rétrécisse- $\unrhd$ ments cicatriciels de l'oesophag par caustique. Ann. \& Chir., 14, 1193.

— Reboud, E., Depieds, R., Humbert, P., and Mercier, C. $\vec{\circ}$ (1960b). Fistule oeso-bronchique par rétrécissement caustique de l'oesophag. Marseille chir., 12, 399.

Gellis, S. S., and Holt, L. E. Jr. (1942). The treatment of lye ingestion by the Salzer method. Ann. Otol. (St. Louis), $\times$ 51, 1086.

Imre, J., and Gergely, M. (1971). Uber die Narbenkarzinome ir des Ösophagus. Thoraxchirurgie, 19, 181.

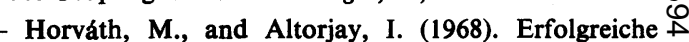
Heilung einer nach korrosionsbedingter, hypopharyngozervikaler Ösophagusstrictur aufgetretenen ösophagobroncho-pleuro-kutanen Fistel mittels substernaler $\overrightarrow{\mathcal{A}}$ Kolonplastik. Thoraxchirurgie, 16, 68.

- and Wooler, G. (1969). Peptic ulceration of the $\frac{\overrightarrow{\mathbb{C}}}{\overparen{D}}$ oesophagus following corrosive burns. Thorax, 24, 762.

Marchand, P. (1965). Caustic strictures of the oesophagus. $\mathbb{D}$ Thorax, 10, 171.

Merendino, K. A., and Dillard, D. H. (1955). The concept of sphincter substitution by an interposed jejunal seg- $N$ ment for anatomic and physiologic abnormalities at the esophagogastric junction. Ann. Surg., 142, 486.

Moody, F. G., and Garrett, J. M. (1969). Esophageal achalasia following lye ingestion. Ann. Surg., 170, 775.

Salzer, H. (1920). Frühbehandlung der Speiseröhrenverätzung. Wien. klin. Wschr., 33, 307.

Sytnik, A. P., and Petrov, B. A. (1968). Cancer of the $\overrightarrow{\bar{O}}$ esophagus in post-burn cicatrical stenosis. In Russian. Khirurgiya (Mosk.), 44, No. 11, p. 3. 